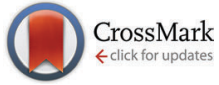

Cite this: Chem. Commun., 2014, 50, 12325

Received 9th June 2014, Accepted 21st August 2014

DOI: $10.1039 / \mathrm{c} 4 \mathrm{cc} 04344 \mathrm{~h}$

www.rsc.org/chemcomm

\section{Spermidinium closo-dodecaborate-encapsulating liposomes as efficient boron delivery vehicles for neutron capture therapy $\dagger$}

\author{
Shoji Tachikawa, ${ }^{a b}$ Tatsuro Miyoshi, ${ }^{b}$ Hayato Koganei, ${ }^{b}$ Mohamed E. El-Zaria, ${ }^{\text {bc }}$ \\ Clara Viñas, ${ }^{d}$ Minoru Suzuki, ${ }^{e}$ Koji Ono ${ }^{e}$ and Hiroyuki Nakamura*ab
}

\begin{abstract}
closo-Dodecaborate-encapsulating liposomes were developed as boron delivery vehicles for neutron capture therapy. The use of spermidinium as a counter cation of closo-dodecaborates was essential not only for the preparation of high boron content liposome solutions but also for efficient boron delivery to tumors.
\end{abstract}

Boron neutron capture therapy (BNCT) has been attracting growing interest as one of the minimally invasive cancer therapies. ${ }^{1}$ Mercaptoundecahydrododecaborate $\left(\mathrm{Na}_{2}\left[\mathrm{~B}_{12} \mathrm{H}_{11} \mathrm{SH}\right] ; \mathrm{Na}_{2} \mathrm{BSH}\right)$ and $\mathrm{L}-p$-boronophenylalanine (L-BPA) have been used in BNCT for many years. L-BPA, in particular, has been widely used for the treatment of not only melanoma but also brain tumor ${ }^{2}$ and head and neck cancer ${ }^{3}$ because it can be taken up selectively by tumor cells through an amino acid transporter. ${ }^{4}$ The accelerator-based BNCT is now undergoing phase I clinical study for the treatment of brain tumor and head and neck cancer patients in Japan.,

In recent years, liposomal ${ }^{10} \mathrm{~B}$ carriers have attracted attention as some of the efficient boron delivery systems in BNCT. ${ }^{7-10}$ Several efficient in vivo BNCTs have been reported. Yanagië and coworkers demonstrated the first antitumor effect of $\mathrm{Na}_{2} \mathrm{BSH}-$ encapsulating liposomes conjugated with a monoclonal antibody specific for the carcinoembryonic antigen..$^{9 a, b}$ Maruyama and co-workers developed transferrin-conjugating $\mathrm{Na}_{2} \mathrm{BSH}$-encapsulating liposomes. ${ }^{9 d, 10}$ Although they succeeded in completely suppressing tumor growth in mice after neutron irradiation, the concentration of inner ${ }^{10} \mathrm{~B}$ of liposomes was limited in preparation due to osmotic reasons. For this reason, boron lipids embedded within the liposome

\footnotetext{
${ }^{a}$ Chemical Resources Laboratory, Tokyo Institute of Technology,

4259 Nagatsuta-cho, Midori-ku, Yokohama 226-8503, Japan.

E-mail: hiro@res.titech.ac.jp; Fax: +81459245244

${ }^{b}$ Department of Chemistry, Faculty of Science, Gakushuin University, Mejiro, Toshima-ku, Tokyo 171-8588, Japan

${ }^{c}$ Department of Chemistry, Faculty of Science, Tanta University, 31527-Tanta, Egypt

${ }^{d}$ Institut de Ciència de Materials de Barcelona (ICMAB-CSIC), Campus U.A.B., 08193 Bellaterra, Barcelona, Spain

${ }^{e}$ Particle Radiation Oncology Research Center, Kyoto University Research Reactor Institute, Asashiro-nishi, Kumatori-cho, Sennan-gun, Osaka 590-0494, Japan $\dagger$ Electronic supplementary information (ESI) available: Experimental details and data. See DOI: $10.1039 / \mathrm{c} 4 \mathrm{cc} 04344 \mathrm{~h}$
}

bilayer have been studied. ${ }^{10-12}$ Hawthorne and coworkers developed liposomes incorporating $\mathrm{Na}_{3}\left[1-\left(2-\mathrm{B}_{10} \mathrm{H}_{9}\right)-2-\mathrm{NH}_{3} \mathrm{~B}_{10} \mathrm{H}_{8}\right]$ into the internal

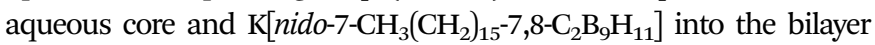
membrane to increase the boron content in liposomes. ${ }^{8 b, 13}$

We previously developed $\mathrm{Na}_{2} \mathrm{BSH}$-encapsulating $10 \%$ distearoyl boron lipid (DSBL) ${ }^{11 b}$ liposomes that have high boron content with excellent boron delivery efficacy to tumors. ${ }^{14}$ In this communication, we studied the effects of the counter cations of boron clusters on liposome formation to develop high boron content liposomes for BNCT by overcoming osmotic pressure limitations.

We selected three closo-dodecaborates, $\mathrm{Na}_{2}\left[\mathrm{~B}_{12} \mathrm{H}_{12}\right]$, $\mathrm{Na}_{2}\left[\mathrm{~B}_{12} \mathrm{H}_{11} \mathrm{OH}\right]^{15}$ and $\mathrm{Na}\left[\mathrm{B}_{12} \mathrm{H}_{11} \mathrm{NH}_{3}\right]^{16}$ in addition to $\mathrm{Na}_{2} \mathrm{BSH}$ (Fig. 1). We first tested the cytotoxicity of the closo-dodecaborates toward colon 26 cells. The closo-dodecaborates are relatively nontoxic and the $\mathrm{GI}_{50}$ values of $\mathrm{Na}_{2}\left[\mathrm{~B}_{12} \mathrm{H}_{12}\right], \mathrm{Na}_{2} \mathrm{BSH}, \mathrm{Na}\left[\mathrm{B}_{12} \mathrm{H}_{11} \mathrm{NH}_{3}\right]$, and $\mathrm{Na}_{2}\left[\mathrm{~B}_{12} \mathrm{H}_{11} \mathrm{OH}\right]$ are 5.1, 2.1,32.9, and $7.7 \mathrm{mM}$, respectively (Table $\mathrm{S} 1$ in the ESI $\dagger$ ). Liposomes containing the closododecaborates were prepared from DSPC, cholesterol, and DSPE-PEG 2000 by the reverse phase evaporation method with sizes of approximately $100 \mathrm{~nm}$ in diameter. The results are summarized in Table 1. The final boron and phosphorus concentrations of liposome solution containing $\mathrm{Na}_{2}\left[\mathrm{~B}_{12} \mathrm{H}_{12}\right]$ were $3438 \pm 2.0$ and $2864 \pm 18.3 \mathrm{ppm}$, respectively, and the $\mathrm{B} / \mathrm{P}$ ratio was 1.2 (entry 1). The higher $\mathrm{B} / \mathrm{P}$ ratio indicates the higher boron content in liposomes. The liposome yield was $58 \%$ based on the total phospholipids used in the preparation. The $\mathrm{B} / \mathrm{P}$ ratio of the liposome containing $\mathrm{Na}\left[\mathrm{B}_{12} \mathrm{H}_{11} \mathrm{NH}_{3}\right]$ was 2.2 (entry 2), which was slightly higher than those of liposomes containing $\mathrm{Na}_{2} \mathrm{BSH}$, $\mathrm{Na}_{2}\left[\mathrm{~B}_{12} \mathrm{H}_{11} \mathrm{OH}\right]$, and $\mathrm{Na}_{2}\left[\mathrm{~B}_{12} \mathrm{H}_{12}\right]$ (1.2-1.6, entries 1, 3, and 4). In the case of $\mathrm{Na}\left[\mathrm{B}_{12} \mathrm{H}_{11} \mathrm{NH}_{3}\right]$, an ammonium ion group served as one of the two counter cations of the closo-dodecaborate

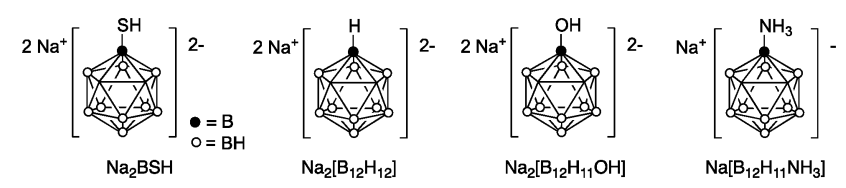

Fig. 1 Structures of closo-dodecaborates used for encapsulation in liposomes. 
Table 1 Physical characteristics of liposomes containing closo-dodecaborates associated with sodium and various ammonium cations ${ }^{a}$

\begin{tabular}{|c|c|c|c|c|c|}
\hline Entry & Boron cluster & $\begin{array}{l}\text { B conc. }{ }^{b, c} \\
\text { (ppm) }\end{array}$ & $\begin{array}{l}\text { P conc. } \\
\text { (ppm) }\end{array}$ & $\mathrm{B} / \mathrm{P}^{b, c}$ & $\begin{array}{l}\text { Yield }^{d} \\
(\%)\end{array}$ \\
\hline 1 & $\mathrm{Na}_{2} \mathrm{BSH}$ & $3438 \pm 2.0$ & $2864 \pm 18.3$ & 1.2 & 58 \\
\hline 2 & $\mathrm{Na}\left[\mathrm{B}_{12} \mathrm{H}_{11} \mathrm{NH}_{3}\right]$ & $4072 \pm 22.8$ & $1835 \pm 38.5$ & 2.2 & 44 \\
\hline 3 & $\mathrm{Na}_{2}\left[\mathrm{~B}_{12} \mathrm{H}_{11} \mathrm{OH}\right]$ & $2635 \pm 184.2$ & $1600 \pm 99.0$ & 1.5 & 39 \\
\hline 4 & $\mathrm{Na}_{2}\left[\mathrm{~B}_{12} \mathrm{H}_{12}\right]$ & $3133 \pm 10.3$ & $1932 \pm 13.3$ & 1.6 & 47 \\
\hline 5 & $\left(n-\mathrm{C}_{3} \mathrm{H}_{7} \mathrm{NH}_{3}\right)_{2} \mathrm{BSH}$ & $2874 \pm 47.7$ & $2225 \pm 15.8$ & 1.3 & 54 \\
\hline 6 & $\left(\mathrm{H}_{3} \mathrm{NC}_{4} \mathrm{H}_{8} \mathrm{NH}_{3}\right) \mathrm{BSH}$ & $4711 \pm 17.4$ & $1833 \pm 43.4$ & 2.6 & 44 \\
\hline 7 & spd-BSH & $13867 \pm 185.8$ & $4046 \pm 18.3$ & 3.4 & 98 \\
\hline 8 & (Sperminium)BSH & $9759 \pm 139.6$ & $3559 \pm 44.5$ & 2.7 & 87 \\
\hline 9 & spd- $\left[\mathrm{B}_{12} \mathrm{H}_{11} \mathrm{NH}_{3}\right]$ & $13970 \pm 216.5$ & $3943 \pm 43.4$ & 3.5 & 95 \\
\hline
\end{tabular}

${ }^{a}$ In all cases, liposomes were prepared from DSPC, cholesterol, and DSPEPEG2000 (1:1: 0.11 , molar ratio) by the REV method. ${ }^{b}$ Data are expressed as means \pm standard deviation (SD). ${ }^{c}$ Boron and phosphorus concentrations of liposome solution were determined by ICP-AES. ${ }^{d}$ Liposome yields were calculated from the phosphorus concentration of liposome solution based on the total phospholipids used in preparation.

dianion. We speculated that ammonium counter cations would affect the encapsulation of closo-dodecaborates in liposomes. Recently, Gabel and coworkers reported that $\mathrm{Na}_{2} \mathrm{BSH}$ induces aggregation and membrane rupture, increasing wall thickness of the liposome and triggering the release of liposome contents. ${ }^{17}$ Indeed, it is known that tetramethylammonium (TMA) salts of closo-dodecaborates are insoluble in water, and the ion-exchange from $\mathrm{Na}_{2} \mathrm{BSH}$ to (TMA) ${ }_{2} \mathrm{BSH}$ proceeds readily, whereas the ionexchange from (TMA) $)_{2} \mathrm{BSH}$ to $\mathrm{Na}_{2} \mathrm{BSH}$ is not easy. We predicted that encapsulation as well as liposome yield would be increased if we could reduce this interaction in the preparation of closododecaborate-encapsulating liposomes. Thus we prepared various ammonium salts of $\mathrm{BSH}$ and examined their encapsulation into liposomes (entries 5-9 in Table 1). The B/P ratio of the liposome containing the $n-\mathrm{C}_{3} \mathrm{H}_{7} \mathrm{NH}_{3}{ }^{+}$salt of $\mathrm{BSH}$ was similar to that of the liposome containing $\mathrm{Na}_{2} \mathrm{BSH}$ (entries 1 vs. 5). The $\mathrm{H}_{3} \mathrm{~N}^{+} \mathrm{C}_{4} \mathrm{H}_{8} \mathrm{NH}_{3}{ }^{+}$ cation increased the $\mathrm{B} / \mathrm{P}$ ratio (2.6) and boron concentration (4711 ppm). Interestingly, the $\mathrm{B} / \mathrm{P}$ ratio dramatically increased to 3.4 when the spermidinium (spd) cation was employed (entry 7). In addition, the liposome yield was markedly increased to $98 \%$ and the final boron concentration of the liposome solution reached $13867 \mathrm{ppm}$. In contrast, the $\mathrm{B} / \mathrm{P}$ ratio of liposome containing (sperminium) BSH dropped to 2.7, although the liposome yield was still high ( $87 \%$ yield) and the final boron concentration of the liposome solution was high at $9759 \mathrm{ppm}$ (entry 8). Liposome containing spd- $\left[\mathrm{B}_{12} \mathrm{H}_{11} \mathrm{NH}_{3}\right]$ showed the highest $\mathrm{B} / \mathrm{P}$ ratio (3.5); the boron concentration of the liposome solution reached $13790 \mathrm{ppm}$ and the liposome yield was 95\% (entry 9).

We examined whether the formation of high boron content liposomes is affected by the viscosity of the closo-dodecaborate solutions. However, the spd cation of $\left[\mathrm{B}_{12} \mathrm{H}_{12}\right]^{2-}$ does not affect the viscosity of internal aqueous solution of liposomes (Table S3, ESI $\dagger$ ). We measured liposome yields and $\mathrm{B} / \mathrm{P}$ ratios under the condition of various ratios of $\mathrm{BSH}$ to spd cations $\left(\mathrm{Na}_{2} \mathrm{BSH}\right.$ : [spermidine $\left.+\mathrm{HCl}\right]=1$ : $X, X=0,0.25,0.5,1$, and 2 ). As shown in Fig. 2 , the $\mathrm{B} / \mathrm{P}$ ratio

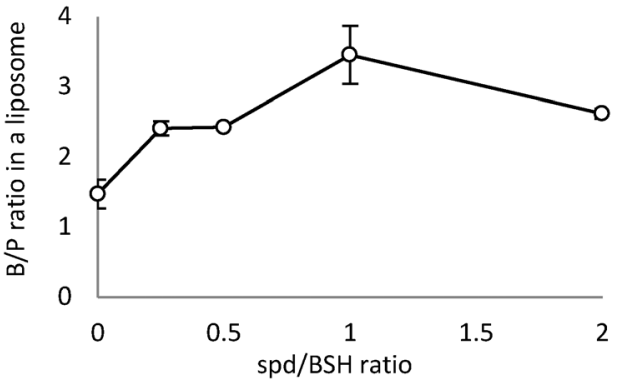

Fig. 2 Effect of the amount of spd cation on spd-BSH encapsulation in liposomes. Boron/phosphorus $(\mathrm{B} / \mathrm{P})$ ratios of $(\mathrm{spd})_{x}$-closo-dodecaborateencapsulating liposomes are shown in the vertical axis.

reached a maximum of 3.4 when the $\mathrm{BSH}$ : spd ratio was 1:1. Liposome yields showed a similar tendency to $\mathrm{B} / \mathrm{P}$ ratios. The highest liposome yield was observed at the BSH to spd cation ratio of $1: 1$. Transmission electron microscopy (TEM) analysis of spd-BSHencapsulating liposomes and $\mathrm{Na}_{2} \mathrm{BSH}$-encapsulating liposomes was also carried out using Cryo-TEM (Fig. 3). It is notable that the liposomes interacted with each other in the case of $\mathrm{Na}_{2} \mathrm{BSH}$ encapsulating liposomes, whereas the liposomes dispersed in solution without interacting with each other in the case of spdBSH-encapsulating liposomes.

We next examined boron distribution of the spd-closododecaborate-encapsulating liposomes in colon 26 tumor-bearing mice. ${ }^{18}$ The liposomes were injected at doses of 15,30 , and $100 \mathrm{mg}$ [B] $\mathrm{kg}^{-1}$ body weight via the tail veins. $\mathrm{Na}_{2} \mathrm{BSH}$ - and $\mathrm{Na}_{2}\left[\mathrm{~B}_{12} \mathrm{H}_{11} \mathrm{NH}_{3}\right]$ encapsulating liposomes were also injected at a dose of $30 \mathrm{mg}[\mathrm{B}] \mathrm{kg}^{-1}$ as control experiments. The time courses of boron distribution in each organ are shown in Fig. 4. Blood boron concentrations of 460.7, 104.0, and $33.2 \mathrm{ppm}$ were detected $24 \mathrm{~h}$ after injection of spd-BSH-encapsulating liposomes (100, 30, and $15 \mathrm{mg}[\mathrm{B}] \mathrm{kg}^{-1}$ ), respectively (Fig. 4a). Blood boron concentration in mice injected with $100 \mathrm{mg}$ [B] $\mathrm{kg}^{-1}$ of spd-BSH-encapsulating liposomes did not decrease notably during the $48 \mathrm{~h}$ period, whereas those in mice injected with 30 and $15 \mathrm{mg}$ [B] kg ${ }^{-1}$ of spd-BSHencapsulating liposomes gradually decreased in a time-dependent manner. The time courses of boron concentrations in liver, kidneys, and spleen are shown in Fig. 4b-d, respectively. Boron concentrations of 528.5, 144.2, and $74.4 \mathrm{ppm}$ in liver were observed $48 \mathrm{~h}$ after the injection of 100,30 , and $15 \mathrm{mg}$ [B] $\mathrm{kg}^{-1}$ of spd-BSHencapsulating liposomes, respectively. In the meantime, maximum

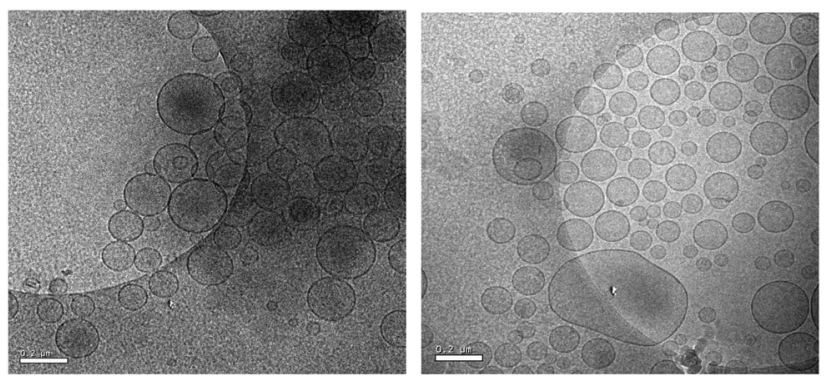

Fig. 3 TEM images of $\mathrm{Na}_{2} \mathrm{BSH}$-encapsulating liposomes (left) and spd$\mathrm{BSH}$-encapsulating liposomes (right). Scale bar represents $200 \mathrm{~nm}$. 


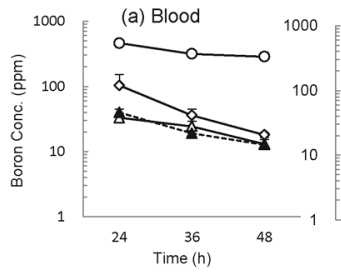

(d) Spleen
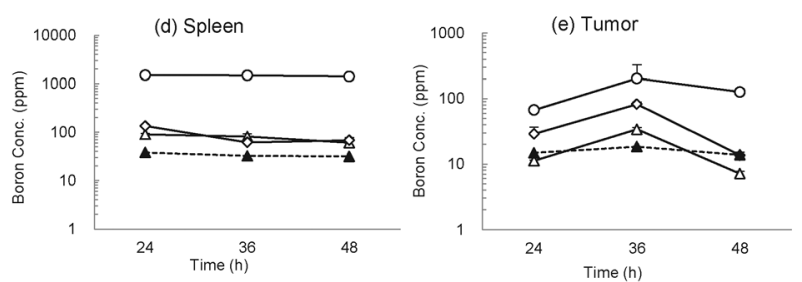

Fig. 4 Time courses of distribution of spd-BSH- and $\mathrm{Na}_{2} \mathrm{BSH}$-encapsulating liposomes $\left(\triangle\right.$, spd-BSH: $15 \mathrm{mg}[\mathrm{B}] \mathrm{kg}^{-1} ; \diamond, \mathrm{spd}-\mathrm{BSH}: 30 \mathrm{mg}[\mathrm{B}] \mathrm{kg}^{-1} ; 0$, spd-BSH: $100 \mathrm{mg}[\mathrm{B}] \mathrm{kg}^{-1} ; \boldsymbol{\Delta}, \mathrm{Na}_{2} \mathrm{BSH}: 15 \mathrm{mg}^{[B]} \mathrm{kg}^{-1}$ ). Each liposome was injected into tumor-bearing mice via the tail vein. Data are expressed as means $\pm \mathrm{SD}(n=5)$.

tumor boron concentrations of 202.7 and $82.4 \mathrm{ppm}$ were achieved $36 \mathrm{~h}$ after injection at doses of 100 and $30 \mathrm{mg}$ [B] $\mathrm{kg}^{-1}$, respectively. Even at the low boron dose of $15 \mathrm{mg}$ [B] $\mathrm{kg}^{-1}$, the tumor boron concentration was $34.0 \mathrm{ppm}$ at $36 \mathrm{~h}$ after injection (Fig. 4e). We also demonstrated the boron distribution of $\mathrm{Na}_{2} \mathrm{BSH}$-encapsulating liposomes in tumor-bearing mice for comparison. Although blood and liver boron concentrations after injection of $\mathrm{Na}_{2} \mathrm{BSH}$ encapsulating liposomes at a dose of $30 \mathrm{mg}[\mathrm{B}] \mathrm{kg}^{-1}$ were similar to those after injection of spd-BSH-encapsulating liposomes at a dose of $30 \mathrm{mg}$ [B] $\mathrm{kg}^{-1}$, kidney and spleen boron concentrations after injection of $\mathrm{Na}_{2} \mathrm{BSH}$-encapsulating liposomes were lower than those after injection of spd-BSH-encapsulating liposomes up to $48 \mathrm{~h}$. The tumor boron concentration at $36 \mathrm{~h}$ after injecting $\mathrm{Na}_{2} \mathrm{BSH}$-encapsulating liposomes was $31.9 \mathrm{ppm}$, although the clearance of $\mathrm{Na}_{2} \mathrm{BSH}$-encapsulating liposomes was slow (Fig. 4e).

A similar tendency was observed in spd-[ $\left[\mathrm{B}_{12} \mathrm{H}_{11} \mathrm{NH}_{3}\right]$-encapsulating liposomes (Fig. S1, ESI $\dagger$ ). Blood, kidney, and spleen boron concentrations gradually decreased after injection. Maximum tumor boron concentrations of 242.2, 88.7, and $35.4 \mathrm{ppm}$ were achieved $6 \mathrm{~h}$ after injection at doses of 100,30 , and $15 \mathrm{mg}$ [B] kg ${ }^{-1}$, respectively. Interestingly, significant tumor boron accumulation was also observed in the case of $\mathrm{Na}\left[\mathrm{B}_{12} \mathrm{H}_{11} \mathrm{NH}_{3}\right]$-encapsulating liposomes.

Finally, we examined the antitumor effect of liposomes containing spd closo-dodecaborates in colon 26 tumor bearing mice exposed to thermal neutron irradiation. Thermal neutron irradiation of the tumor-transplanted left thighs of mice was carried out $36 \mathrm{~h}$ after injection. The tumor growth curves of mice are shown in Fig. 5 (and in Fig. S2, ESI $\dagger$ ). "Hot control (- -)" and "Cold control (-×-)" represent tumor volumes of mice injected with saline with and without thermal neutron irradiation, respectively. Tumor growth was significantly suppressed in mice treated with spd- $-\left[{ }^{10} \mathrm{BSH}\right]$ - and $\mathrm{spd}-\left[{ }^{10} \mathrm{~B}_{12} \mathrm{H}_{11} \mathrm{NH}_{3}\right]$-encapsulating liposomes at doses of 15,30 , and $100 \mathrm{mg}\left[{ }^{10} \mathrm{~B}\right] \mathrm{kg}^{-1}$ and exposed to thermal neutron irradiation. The tumor completely disappeared within three weeks even when a dose of $15 \mathrm{mg}\left[{ }^{10} \mathrm{~B}\right] \mathrm{kg}^{-1}$ was employed. Liposomes containing $\mathrm{Na}_{2}\left[{ }^{10} \mathrm{BSH}\right]$ and $\mathrm{Na}\left[{ }^{10} \mathrm{~B}_{12} \mathrm{H}_{11} \mathrm{NH}_{3}\right]$

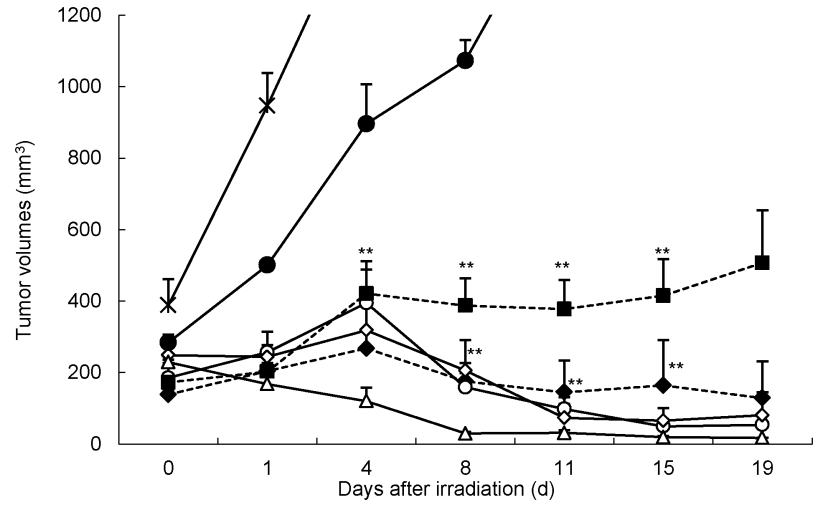

Fig. 5 Tumor volumes in mice (Balb/c, female, six weeks old, 14-20 g) bearing colon 26 solid tumor, exposed to thermal neutron irradiation (hot) for 50 min $\left(1.3-2.2 \times 10^{12}\right.$ neutrons per $\left.\mathrm{cm}^{2}\right)$ or not exposed to thermal neutron irradiation (cold). Irradiation was performed $36 \mathrm{~h}$ after injection of liposomes containing spd- $\left[{ }^{10} \mathrm{BSH}\right]\left(\triangle, 15 ; \diamond, 30 ; \bigcirc, 100 \mathrm{mg}\left[{ }^{10} \mathrm{~B}\right] \mathrm{kg}^{-1}\right)$ and $\mathrm{Na}_{2}\left[{ }^{10} \mathrm{BSH}\right]\left(\bullet, 30 \mathrm{mg}\left[{ }^{10} \mathrm{~B}\right] \mathrm{kg}^{-1}\right)$, or $1 \mathrm{~h}$ after injection of $\mathrm{Na}_{2}\left[{ }^{10} \mathrm{BSH}\right]$ solution (, $100 \mathrm{mg}\left[{ }^{10} \mathrm{~B}\right] \mathrm{kg}^{-1}$ ). $\bullet$, hot control; $\times$, cold control. ${ }^{*} P<<0.01$, compared with hot control.

also inhibited tumor growth at a dose of $30 \mathrm{mg}\left[{ }^{10} \mathrm{~B}\right] \mathrm{kg}^{-1}$, and the tumor was completely controlled three weeks after thermal neutron irradiation. Tumor growth was suppressed in mice treated with $\mathrm{Na}_{2}\left[{ }^{10} \mathrm{BSH}\right]$ solution $\left(100 \mathrm{mg}\left[{ }^{10} \mathrm{~B}\right] \mathrm{kg}^{-1}\right)$ during the two weeks after thermal neutron irradiation. However, the tumor started to grow thereafter (Fig. 5). In contrast, tumor growth was not suppressed in mice treated with $\mathrm{Na}\left[{ }^{10} \mathrm{~B}_{12} \mathrm{H}_{11} \mathrm{NH}_{3}\right]$ solution (100 mg $\left[{ }^{10} \mathrm{~B}\right] \mathrm{kg}^{-1}$ ) even after thermal neutron irradiation (Fig. S2, ESI $\dagger$ ).

Fig. 6 shows the survival curve of tumor-bearing mice after thermal neutron irradiation. All untreated mice without thermal neutron irradiation died within two weeks. Thermal neutron irradiation enhanced mouse survival and all mice exposed to thermal neutron irradiation died within 78 days. Prolonged survival was observed in mice injected with spd- $\left[{ }^{10} \mathrm{BSH}\right]$ - and $\operatorname{spd}-\left[{ }^{10} \mathrm{~B}_{12} \mathrm{H}_{11} \mathrm{NH}_{3}\right]$ encapsulating liposomes; $72 \%$ of the mice that received a dose of $15 \mathrm{mg}\left[{ }^{10} \mathrm{~B}\right] \mathrm{kg}^{-1}$ survived up to 100 days after the thermal neutron irradiation. Furthermore, a remarkable antitumor effect

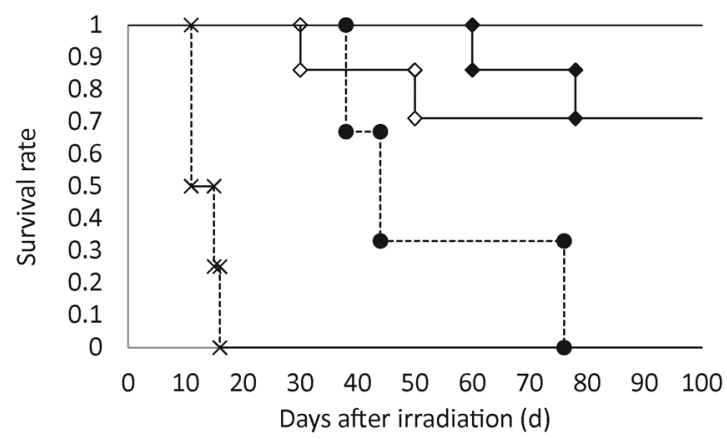

Fig. 6 Survival curve of tumor-bearing mice after thermal neutron irradiation. The irradiation was performed $36 \mathrm{~h}$ after injection of closo-dodecaborates (一, spd-BSH: $30 \mathrm{mg}\left[{ }^{10} \mathrm{~B}\right] \mathrm{kg}^{-1}$; $\diamond$, spd-BSH: $15 \mathrm{mg}\left[{ }^{10} \mathrm{~B}\right] \mathrm{kg}^{-1} ; \diamond$, spd- $\left.{ }^{10} \mathrm{~B}_{12} \mathrm{H}_{11} \mathrm{NH}_{3}: 15 \mathrm{mg}\left[{ }^{10} \mathrm{~B}\right] \mathrm{kg}^{-1}\right)$ for 50 min $\left(1.3-2.2 \times 10^{12}\right.$ neutrons per $\mathrm{cm}^{2}$ ). $\times$, cold control; $\bullet$, hot control. Mice were sacrificed when their tumor volumes reached $\sim 3000 \mathrm{~mm}^{3}$. 
was observed in the mice treated with spd- $\left[{ }^{10} \mathrm{BSH}\right]-$ encapsulating liposomes at a dose of $30 \mathrm{mg}\left[{ }^{10} \mathrm{~B}\right] \mathrm{kg}^{-1} ; 100 \%$ of the mice survived up to 100 days after the thermal neutron irradiation.

We succeeded in the preparation of high boron content liposomes. The use of spd as a counter cation of closo-dodecaborates was essential to obtain the liposomes with high yields and high $\mathrm{B} / \mathrm{P}$ ratios. All of the mice injected with $30 \mathrm{mg}\left[{ }^{10} \mathrm{~B}\right] \mathrm{kg}^{-1}$ of spd- $\left[{ }^{10} \mathrm{BSH}\right]$ encapsulating liposomes were completely cured while five of seven mice injected with $15 \mathrm{mg}\left[{ }^{10} \mathrm{~B}\right] \mathrm{kg}^{-1}$ of $\mathrm{spd}-\left[{ }^{10} \mathrm{BSH}\right]$ - and spd- $\left[{ }^{10} \mathrm{~B}_{12} \mathrm{H}_{11} \mathrm{NH}_{3}\right]$-encapsulating liposomes were cured 100 days after thermal neutron irradiation. The results indicate that the total amount of phospholipids could be reduced to less than one-seventh of those used to prepare $\mathrm{Na}_{2}\left[{ }^{10} \mathrm{BSH}\right]$-encapsulating liposomes. ${ }^{19}$ We believe that the spd-closo-dodecaborateencapsulating liposomes are promising candidates for clinical use in BNCT.

We thank Dr S. Kondoh (Teijin Pharm. Co. Ltd) for the measurement of osmotic pressures and Professor K. Iwata (Gakushuin University) for the measurement of the viscosity. This work was supported by Health and Labor Sciences Research Grants for research on Nanotechnical Medical from the Ministry of Health, Labor and Welfare (20100201) and the Ministry of Education, Science, Sports, Culture and Technology, Grant-inAid for Scientific Research (B) (No. 23390018) from Japan.

\section{Notes and references}

1 (a) R. F. Barth, J. A. Coderre, M. G. Vicente and T. E. Blue, Clin. Cancer Res., 2005, 11, 3987; (b) T. Yamamoto, K. Nakai and A. Matsumura, Cancer Lett., 2008, 262, 143; (c) H. Hatanaka, J. Neurol., 1975, 209, 81.

2 S.-I. Miyatake, Y. Tamura, S. Kawabata, K. Iida, T. Kuroiwa and K. Ono, Neurosurgery, 2007, 61, 82.

3 (a) I. Kato, K. Ono, Y. Sakurai, M. Ohmae, A. Maruhashi, Y. Imahori, M. Kirihata, M. Nakazawa and Y. Yura, Appl. Radiat. Isot., 2004, 61, 1069; (b) T. Aihara, J. Hiratsuka, N. Morita, M. Uno, Y. Sakurai, A. Maruhashi, K. Ono and T. Harada, Head Neck, 2006, 28, 850; (c) L. Kankaanranta, T. Seppälä, H. Koivunoro, K. Saarilahti, T. Atula, J. Collan, E. Salli, M. Kortesniemi, J. Uusi-Simola, A. Mäkitie, M. Seppänen, H. Minn, P. Kotiluoto, I. Auterinen, S. Savolainen, M. Kouri and H. Joensuu, Int. J. Radiat. Oncol., Biol., Phys., 2007, 69, 475.

4 (a) Y. Takahashi, Y. Imahori and K. Mineura, Clin. Cancer Res., 2003, 9, 5888; (b) A. Wittig, W. A. Sauerwein and J. A. Coderre, Radiat. Res., 2000, 153, 173; (c) G. W. Kabalka and M. L. Yao, Anticancer Agents Med. Chem., 2006, 6, 111; (d) Y. Imahori, Y. Ohmori, R. Fujii, K. Matsumoto and S. Ueda, Cancer Res., 1995, 55, 4225.

5 M. Suzuki, H. Tanaka, Y. Sakurai, G. Kashino, L. Yong, S. Masunaga, Y. Kinashi, T. Mitsumoto, S. Yajima, H. Tsutsui, T. Sato, A. Maruhashi and K. Ono, Radiother. Oncol., 2009, 92, 89.
6 H. Tanaka, Y. Sakurai, M. Suzuki, T. Takata, S. Masunaga, Y. Kinashi, G. Kashino, Y. Liu, T. Mitsumoto, S. Yajima, H. Tsutsui, M. Takada, A. Maruhashi and K. Ono, Appl. Radiat. Isot., 2009, 67, S258.

7 H. Nakamura, Future Med. Chem., 2013, 5, 715.

8 For passive targeting, see: (a) K. Shelly, D. A. Feakes, M. F. Hawthorne, P. G. Schmidt, T. A. Krisch and W. F. Bauer, Proc. Natl. Acad. Sci. U. S. A., 1992, 89, 9039; (b) D. A. Feakes, K. Shelly and M. F. Hawthorne, Proc. Natl. Acad. Sci. U. S. A., 1995, 92, 1367.

9 For active targeting, see: $(a)$ H. Yanagië, T. Tomita, H. Kobayashi, Y. Fujii, T. Takahashi, K. Hasumi, H. Nariuchi and M. Sekiguchi, $B r$. J. Cancer, 1991, 63, 522; (b) H. Yanagië, T. Tomita, H. Kobayashi, Y. Fujii, Y. Nonaka, Y. Saegusa, K. Hasumi, M. Eriguchi, T. Kobayashi and K. Ono, Br. J. Cancer, 1997, 75, 660; (c) X. Q. Pan, H. Wang, S. Shukla, M. Sekido, D. M. Adams, W. Tjarks, R. F. Barth and R. J. Lee, Bioconjugate Chem., 2002, 13, 435; (d) K. Maruyama, O. Ishida, S. Kasaoka, T. Takizawa, N. Utoguchi, A. Shinohara, M. Chiba, H. Kobayashi, M. Eriguchi and H. Yanagie, J. Controlled Release, 2004, 98, 195.

10 Y. Miyajima, H. Nakamura, Y. Kuwata, J.-D. Lee, S. Masunaga, K. Ono and K. Maruyama, Bioconjugate Chem., 2006, 17, 1314.

11 (a) H. Nakamura, Y. Miyajima, T. Takei, S. Kasaoka and K. Maruyama, Chem. Commun., 2004, 1910; (b) J.-D. Lee, M. Ueno, Y. Miyajima and H. Nakamura, Org. Lett., 2007, 9, 323; (c) M. Ueno, H. S. Ban, K. Nakai, R. Inomata, Y. Kaneda, A. Matsumura and H. Nakamura, Bioorg. Med. Chem., 2010, 18, 3059.

12 (a) T. Li, J. Hamdi and M. F. Hawthorne, Bioconjugate Chem., 2006, 17, 15; (b) E. Justus, D. Awad, M. Hohnholt, T. Schaffran, K. Edwards, G. Karlsson, L. Damian and D. Gabel, Bioconjugate Chem., 2007, 18, 1287; (c) X. Pan, G. Wu, W. Yang, R. F. Barth, W. Tjarks and R. J. Lee, Bioconjugate Chem., 2007, 18, 101.

13 P. J. Kueffer, C. A. Maitz, A. A. Khan, S. A. Schuster, N. I. Shlyakhtina, S. S. Jalisatgi, J. D. Brockman, D. W. Nigg and M. F. Hawthorne, Proc. Natl. Acad. Sci. U. S. A., 2013, 110, 6512.

14 H. Koganei, M. Ueno, S. Tachikawa, L. Tasaki, H. S. Ban, M. Suzuki, K. Shiraishi, K. Kawano, M. Yokoyama, Y. Maitani, K. Ono and H. Nakamura, Bioconjugate Chem., 2013, 24, 124.

15 T. Peymann, C. B. Knobler and M. F. Hawthorne, Inorg. Chem., 2000, 39, 1163.

16 W. R. Hertler and M. S. Raasch, J. Am. Chem. Soc., 1964, 86, 3661.

17 (a) D. Gabel, D. Awad, T. Schaffran, D. Radovan, D. Daraban, L. Damian, M. Winterhalter, G. Karlsson and K. Edwards, ChemMedChem, 2007, 2, 51; (b) D. Awad, L. Damian, M. Winterhalter, G. Karlsson, K. Edwards and D. Gabel, Chem. Phys. Lipids, 2009, 157, 78.

18 All protocols were approved by the Institutional Animal Care and Use Committee of Gakushuin University.

19 Conventionally, a preinjection of liposome at a high dose was given for an achievement of targeting through saturation of liver's scavenging capacity (see; Y. Y. Kao and R. L. Juliano, Biochim. Biophys. Acta, 1981, 677, 453). Such a high liposome dose may cause possible liver toxicity, since the liver's normal scavenging function is impaired. Indeed, an important character of an approved liposomal formulation (doxil) encapsulating an anticancer drug doxorubicin is the very high concentration of the encapsulated drug (also see; P. G. Tardi, N. L. Boman and P. R. Cullis, J. Drug Targeting, 1996, 4, 129). 